\title{
THE INFLUENCE OF CEMENT BYPASS DUST ON THE PROPERTIES OF CEMENT CURING UNDER NORMAL AND AUTOCLAVE CONDITIONS
}

\author{
WPŁYW PYŁU Z INSTALACJI BYPASSA PIECA CEMENTOWEGO \\ NA WŁAŚCIWOŚCI CEMENTU DOJRZEWAJĄCEGO W WARUNKACH \\ NORMALNYCH I AUTOKLAWIZACJI
}

DOI: 10.30540/sae-2019-001

\begin{abstract}
This paper analyses the properties of cement binders composed with cement CEM I 42.5R and cement bypass dust in amount of 0.5, 1.0 and 5.0\% by mass of binder, curing under standard and additionally autoclave conditions. The bypass dust increases the water content for standard consistency and delays the initial setting time of binder. The cement paste containing 5\% of dust reveals the change in volume by $6 \mathrm{~mm}$ according to Le Chatelier test. After 2 days, the compressive strength of cement mortar containing bypass is comparable to that of Portland cement mortar, but at later time the strength development of this cement binder is slower. The addition of cement bypass dust in amount to 1\% can obtain the cement of strength class of 42.5R according to standard PN-EN 197-1. The autoclave curing improves the compressive strength of cement mortar. The SEM/EDS observations confirm the presence of low crystalline $C$-S-H gel and well-formed tobermorite fibres in autoclaved cement mortar containing $5 \%$ of cement bypass dust.
\end{abstract}

Keywords: cement bypass dust, curing condition, standard consistency, initial setting time, soundness, compressive strength, SEM/EDS analysis

\begin{abstract}
Streszczenie
W pracy analizowano właściwości spoiw cementowych zawierajacych $w$ składzie cement portlandzki CEM I 42,5R i pyt $z$ instalacji bypassa pieca cementowego w ilości 0,5, 1,0 i 5,0\% masy spoiwa, dojrzewajacych w warunkach normalnych i dodatkowo w autoklawie. Pyt z bypassa zwiększa ilość wody niezbędnej do uzyskania konsystencji normowej oraz opóźnia początek czasu wiąania spoiwa. Zaczyn zawierajacy 5\% pyłu wykazuje zmianę objętości o $6 \mathrm{~mm}$ wedtug Le Chateliera. Po dwóch dniach wytrzymatość na ściskanie zaprawy ze spoiwa zawierającego pyt z bypassa jest porównywalna $z$ wytrzymatościa zaprawy z cementu portlandzkiego, ale w miare upływu czasu przyrost wytrzymalości zaprawy z tego spoiwa jest mniejszy. Dodatek pylu z bypassa w ilości nieprzekraczajacej $1 \%$ pozwala otrzymać cement klasy wytrzymatości 42,5R wedlug wymagań normy PN-EN 197-1. Autoklawizacja zwiększa wytrzymatość na ściskanie zaprawy cementowej, a pył z bypassa stanowi jeden z czynników poprawiajacych właściwości wytrzymatościowe. Obserwacje SEM/EDS potwierdzaja obecność stabo wykrystalizowanego żelu C-S-H i dobrze wykształconych wtókien tobermorytu w próbce zaprawy zawierajacej 5\% pyt z bypassa dojrzewającej $w$ warunkach autoklawu.
\end{abstract}

Slowa kluczowe: pył z instalacji bypassa pieca cementowego, warunki dojrzewania, konsystencja normowa, początek czasu wiązania, stałość objętości, wytrzymałość na ściskanie, analiza SEM/EDS

\section{INTRODUCTION}

Due to the character of the technological process, the cement industry is a significant source of dust and gas emissions. In the production process of Portland cement clinker (semi-finished product in the

\section{WPROWADZENIE}

Ze względu na charakter procesu technologicznego przemysł cementowy jest znaczącym źródłem emisji pyłów i gazów. W procesie produkcji klinkieru portlandzkiego (półproduktu w produkcji ce- 
cement manufacturing) the large amounts of dusts are released, among others the dusts from the kiln dedusting installation (specified as CKD - Cement Kiln Dust) and dusts from bypass installation (CBPD - Cement By-Pass Dust). The CBPD can be divided into two types depending on the place from which they are taken: dust collected right at the cold end of the kiln and after the addition of limestone powder to prevent clogged drain pipes [1-4].

The CKD is always released in the cement production process, in opposite to CBPD, because the bypass installation is only used in certain specific cases, for reducing the chlorine and alkalis.

The quality of CBPD depends on the clinker burning technology, the type of raw materials and fuels used in production of clinker and the method for removing dust from material $[5,6]$. The CBPD differs in chemical and mineral composition and physical properties [7-10].

The CBPD is characterized by high concentration of chlorine in relation to $\mathrm{CKD}$, for which the concentration of chlorine is marginally. The other significant difference is the content of $\mathrm{K}_{2} \mathrm{O}$ and $\mathrm{SO}_{3}$. The content of potassium and sulphur in CBPD can be even 2-2,5 times higher than that in CKD [11-13].

Because of the Portland cement clinker production is constantly increasing, the amount of emitted cement dusts, including also CBPD dust, is also increasing. From this reason, the utilization of bypass dust in different industries is more and more broadly discussed. Nowadays, the bypass dust is used for example in production of cement and glass, for construction of roads and highways and manufacture of concrete. The application of this waste in the field of solid stabilization is also a major interest [14-16].

The quality chemical composition of CBPD is compared to raw feed used for cement clinker production $[4,17]$. The main oxide in bypass dust is $\mathrm{CaO}$, which concentration, as it is shown by authors $[7,12,18,19]$, is in the range of 40 to $60 \%$. The other components are $\mathrm{SiO}_{2}, \mathrm{Al}_{2} \mathrm{O}_{3}, \mathrm{Fe}_{2} \mathrm{O}_{3}, \mathrm{~K}_{2} \mathrm{O}$ and $\mathrm{Na}_{2} \mathrm{O}$. In comparison to Portland cement clinker, the bypass dust is characterized by high content of alkalis, especially $\mathrm{K}_{2} \mathrm{O}$, chlorides and $\mathrm{SO}_{3}$. The concentration of these oxides in bypass dust is determined by the type of fuel using in cement production, especially by using alternative fuels such as plastics, bone meal, sewage sludge, etc. This high concentration of alkalis, chlorine and sulphur mentu) wydzielane są duże ilości pyłów m.in. pyłów z pieców do wypalania klinkieru: $\mathrm{z}$ instalacji odpylania pieca (określanych skrótem CKD $-z$ ang. Cement Kiln Dust) oraz z filtrów obejściowych bypassa (CBPD $z$ ang. Cement Bypass Dust). Pyły CBPD można podzielić na dwa rodzaje w zależności od miejsca, z którego są pobierane: pyły odbierane zaraz przy zimnym końcu pieca oraz po dodaniu mączki wapiennej w celu zapobiegania zatykaniu przewodów [1-4].

Pyły CKD są zawsze wytwarzane w procesie produkcji cementu, w przeciwieństwie do pyłów CBPD, gdyż instalacja bypassa jest używana tylko w pewnych specyficznych wypadkach w celu ograniczenia poziomu chloru i alkaliów.

Jakość pyłów z bypassa jest uzależniona od technologii wypalania klinkieru, rodzaju stosowanych surowców i paliw oraz sposobu odpylania materiału $[5,6]$. Pyły te są zróżnicowane pod względem składu chemicznego, mineralnego i właściwości fizycznych [7-10].

Pył CBPD charakteryzuje się wysoką zawartością chloru w stosunku do pyłu CKD, gdzie udział chloru jest marginalny. Kolejna istotna różnica dotyczy zawartość $\mathrm{K}_{2} \mathrm{O}$ i SO $\mathrm{S}_{3}$, których górna zawartość w pyle CBPD może być nawet 2-2,5 razy większa niż w pyle CKD [11-13].

Ponieważ produkcja klinkieru portlandzkiego stale rośnie, wzrasta także ilość emitowanych pyłów cementowych, w tym pyłu CBPD. Z tego powodu coraz częściej dyskutuje się na temat wykorzystania pyłu $\mathrm{z}$ bypassa $\mathrm{w}$ różnych branżach. Obecnie jest on wykorzystywany na przykład $\mathrm{w}$ technologii produkcji cementu i szkła, do budowy dróg i autostrad oraz $\mathrm{w}$ produkcji betonu. Zainteresowaniem cieszy się również stosowanie tego odpadu do stabilizacji gruntów [14-16].

Jakościowy skład chemiczny pyłu CBPD jest zbliżony do składu mączki surowcowej stanowiącej nadawę surowcową pieca do produkcji klinkieru portlandzkiego [4, 17] Podstawowym tlenkiem w pyle jest $\mathrm{CaO}$, którego udział, jak wskazują wyniki badań $[7,12,18,19]$, wynosi od $40 \%$ do $60 \%$. Pozostałymi tlenkami są: $\mathrm{SiO}_{2}, \mathrm{Al}_{2} \mathrm{O}_{3}, \mathrm{Fe}_{2} \mathrm{O}_{3}, \mathrm{~K}_{2} \mathrm{O}$ i Na $\mathrm{Na}_{2} \mathrm{O}$. $\mathrm{W}$ porównaniu do klinkieru portlandzkiego pył $\mathrm{z}$ bypassa charakteryzuje się wysokim udziałem alkaliów, zwłaszcza $\mathrm{K}_{2} \mathrm{O}$, chlorków i $\mathrm{SO}_{3}$. Zawartość tych tlenków w pyle zależy od rodzaju paliwa stosowanego do produkcji cementu, zwłaszcza w przypadku stosowania paliw alternatywnych, takich jak tworzywa sztuczne, mączka kostna, osady ściekowe itp. Ta wysoka koncentracja alkaliów, chlorków i siarki znaczą- 
significantly limits the possibility of using cement bypass dust in cement production $[8,10,17,18,20]$.

The main phase compounds in CBPD are: sylvite (potassium chloride $-\mathrm{KCl}$ ), halite (sodium chloride $\mathrm{NaCl})$, free lime $(\mathrm{CaO})$, anhydrite $-\mathrm{CaSO}_{4}$, calcite $\mathrm{CaCO}_{3}$, quartz $-\mathrm{SiO}_{2}$, calcium hydroxide $-\mathrm{Ca}(\mathrm{OH})_{2}$ and belite $[4,10,17,19]$.

The influence of bypass dust on the cement properties was investigated in papers $[3,18,21$ 23]. The introduction of CBPD dust into the cement causes the increase in water required to obtain cement paste of standard consistency. At $10 \%$ addition of CBPD, the water demand is increased by about $22 \%$ as compared to Portland cement paste [3]. It is probably due to greater fineness of CBPD than that of typical Portland cement. The paper [3] showed that the increase in initial setting time of cement paste containing $10 \%$ of CBPD is shorten by about $45 \%$. The compressive strength of cement mortar containing CBPD is comparable to that of ordinary Portland cement, but only if the content of CBPD dust does not exceed $6 \%$, which is confirmed in paper [18] (the drop in compressive strength is equal to the so-called "dilution effect" of the cement component in the binder).

At higher addition of bypass dust, the higher decrease in compressive strength is denoted, for example up to $30 \%$, when the content of bypass dust in the binder is $10 \%$. A large impact on the cement mortar strength is the high content of free (unbound) $\mathrm{CaO}$ in the bypass dust. The free lime is characterized by high reactivity and quickly reacts with water. The hydration of $\mathrm{CaO}$ leads to form of $\mathrm{Ca}(\mathrm{OH})_{2}$, which molar volume is greater than molar volume of $\mathrm{CaO}$. In effect, the stretching stresses are formed in the material, defined as uneven volume changes during hardening cement. The consequence of that may be lower mechanical strength and destructive changes of cement mortar.

In the literature, the much attention has been given to the characteristics of CKD dust and its effect on the cement properties. However, there are fewer works on the properties of cement containing CBPD dust.

The aim of this paper is the analysis of properties of cement binder containing cement dust from bypass installation. The three cement binders were prepared in which CBPD dust was a partial substitute for Portland cement CEM I 42.5R, and its content was $0.5 \%, 1.0 \%$ or $5.0 \%$ by mass of cement binder (BCPD dust as a secondary component for cement production). The standard consistency, initial setting co ogranicza możliwość zastosowania pyłu z bypassa w produkcji cementu $[8,10,17,18,20]$.

Głównymi składnikami mineralnymi w CBPD są: sylwin (chlorek potasu $-\mathrm{KCl}$ ), halit (chlorek sodu $\mathrm{NaCl}$ ), wolne wapno - $\mathrm{CaO}$, anhydryt $-\mathrm{CaSO}_{4}$, kalcyt $-\mathrm{CaCO}_{3}$, kwarc $-\mathrm{SiO}_{2}$, wodorotlenek wapnia $\mathrm{Ca}(\mathrm{OH})_{2}$ oraz belit $[4,10,17,19]$.

Wpływ pyłu z bypassa na właściwości cementu analizowano w pracach [3, 18, 21-23]. Wprowadzenie do składu cementu CBPD zwiększa wzrost ilości wody niezbędnej do uzyskania zaczynu o konsystencji normowej. Przy dodatku 10\% pyłu CBPD ilość wymaganej wody wzrasta o około $22 \%$ w stosunku do zaczynu z cementu portlandzkiego [3]. Jest to prawdopodobnie spowodowane znacznie większą miałkością pyłu CBPD w stosunku do typowego cementu portlandzkiego. W pracy [3] wykazano, że początek czasu wiązania zaczynu zawierającego $10 \%$ CBPD ulega skróceniu o około 45\%. Wytrzymałość na ściskanie zaprawy zawierającej pył CBPD jest porównywalna $\mathrm{z}$ wytrzymałością cementu portlandzkiego, ale tylko wtedy, gdy udział pyłu CBPD w spoiwie nie przekracza $6 \%$, co potwierdzają wyniki badań [18] (spadek wytrzymałości jest równy tzw. „efektowi rozcieńczenia" składnika cementowego w spoiwie).

Przy większym udziale pyłu z bypassa obserwuje się większy spadek wytrzymałości zaprawy, np. nawet do $30 \%$, gdy udział pyłu w spoiwie wynosi $10 \%$. Znaczący wpływ na wytrzymałość zaprawy ma wysoki udział wolnego (niezwiązanego) $\mathrm{CaO}$ w pyle. Wolne $\mathrm{CaO}$ charakteryzuje się wysoką reaktywnością i szybko reaguje $\mathrm{z}$ wodą. Hydratacja $\mathrm{CaO}$ prowadzi do powstania $\mathrm{Ca}(\mathrm{OH})_{2}$, którego objętość molowa jest dużo większa niż objętość molowa $\mathrm{CaO}$. W efekcie w materiale powstają naprężenia rozciągające, określane jako nierównomierne zmiany objętości podczas twardnienia. Konsekwencją tego może być obniżona wytrzymałość mechaniczna i zmiany destrukcyjne zaprawy cementowej.

W literaturze wiele uwagi poświęcono charakterystyce pyłu CKD i jego wpływowi na właściwości cementu. Natomiast mniej jest prac na temat właściwości cementu zawierającego w składzie pył CBPD.

Celem niniejszej pracy jest analiza właściwości spoiwa cementowego zawierającego w składzie pył cementowy $z$ instalacji bypassa. Przygotowano trzy spoiwa cementowe, w których pył CBPD był traktowany jako częściowym substytut cementu portlandzkiego CEM I 42,5R, a jego udział wynosił 0,5\%, $1,0 \%$ lub 5,0\% masy spoiwa (pył CBPD jako składnik drugorzędny w produkcji cementu). Oznaczono kon- 
time, soundness and compressive strength of cement binder was designated. The strength researches were made for cement mortars cured under normal and autoclave conditions. In final research stage, the SEM/EDS observations of microstructure of cement mortar were made.

\section{EXPERIMENT}

\subsection{Materials}

The Portland cement CEM I 42.5R (OPC Ordinary Portland Cement) used in this experiment came from one of the Polish cement plant. Its chemical composition is shown in Table 1. The phase composition was calculated from Bogue's formulas [24]: $67.9 \% \mathrm{C}_{3} \mathrm{~S}, 6.9 \% \beta-\mathrm{C}_{2} \mathrm{~S}, 7.4 \% \mathrm{C}_{3} \mathrm{~A}$ and $6.8 \%$ $\mathrm{C}_{4} \mathrm{AF}$.

The cement dust used in the experiment came from the bypass installation of the rotary kiln in the production of Portland cement clinker from the same cement plant. The chemical composition of the bypass dust is shown in Table 1. Its phase composition was determined by X-ray quality diffractometry. The XRD pattern of CBPD is shown in Figure 1.

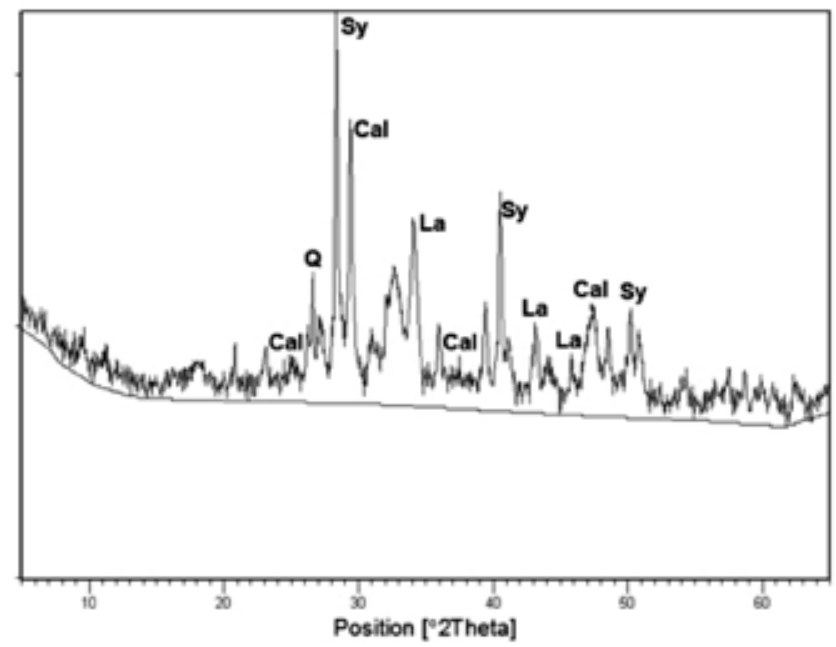

As it is shown in Table 1, the specific density of CBPD is about $2.42 \mathrm{~kg} / \mathrm{m}^{3}$, whereas its specific surface area, determining by Blaine's method, is $8450 \mathrm{~cm}^{2} / \mathrm{g}$ (2-times higher than that of cement CEM I 42.5R). The specific density of bypass dust is on the range of $2.6-2.8 \mathrm{~kg} / \mathrm{m}^{3}$, and its specific surface area - from $4600 \mathrm{~cm}^{2} / \mathrm{g}$ to even $14000 \mathrm{~cm}^{2} / \mathrm{g}[10,25,26]$. In grain size distribution is dominated by finer grains with diameter below $32 \mu \mathrm{m}$ (about $75 \%$ by mass of bypass dust), and the maximum grain size does not exceed $300 \mu \mathrm{m}$. systencję normową, początek czasu wiązania, stałość objętości oraz wytrzymałość na ściskanie spoiw cementowych. Badania wytrzymałości dotyczyły zapraw dojrzewających w warunkach normalnych oraz po procesie autoklawizacji. Końcowy etap badań obejmował obserwacje mikrostruktury zapraw cementowych metodą SEM/EDS.

\section{CZESŚĆ EKSPERYMENTALNA}

\subsection{Materiały}

W badaniach zastosowano cement portlandzki CEM I 42,5R (OPC - z ang. Ordinary Portland Cement), który pochodził $\mathrm{z}$ jednego $\mathrm{z}$ polskich zakładów cementowych. Jego skład chemiczny przedstawiono w tabeli 1. Skład fazowy obliczono ze wzorów Bogue'a [24]. Wynosił on $67,9 \% \mathrm{C}_{3} \mathrm{~S}, 6,9 \% \beta_{-} \mathrm{C}_{2} \mathrm{~S}$, $7,4 \% \mathrm{C}_{3} \mathrm{~A}$ i $6,8 \% \mathrm{C}_{4} \mathrm{AF}$.

Pył cementowy użyty w badaniach pochodził $\mathrm{z}$ instalacji bypassa pieca obrotowego do wypalania klinkieru portlandzkiego i był dostarczony $\mathrm{z}$ tej samej cementowni. Skład chemiczny pyłu pokazano w tabeli 1. Jego skład fazowy określono metodą jakościowej dyfraktometrii rentgenowskiej. Dyfraktogram XRD of CBPD przedstawiono na rysunku 1.

Fig. 1. The XRD pattern of cement bypass dust: Cal-calcite, $Q$-quartz, Sy-sylvine, Be-belite, $L$-lime (CaO)

Rys. 1. Dyfraktogram XRD pytu cementowego z bypassa: Cal-kalcyt, $Q-k w a r c, S y-s y l w i n, B e-b e l i t, L-w a p n o$ (CaO)

Jak przedstawiono w tabeli 1 , pył z bypassa wykazuje gęstość właściwą około $2,42 \mathrm{~kg} / \mathrm{m}^{3}$, natomiast jego powierzchnia właściwa, mierzona metodą Blaine'a, wynosi $8450 \mathrm{~cm}^{2} / \mathrm{g}$ (dwukrotnie większa niż cementu CEM I 42,5R). Gęstość właściwa pyłu z bypassa zmienia się w zakresie $2,6-2,8 \mathrm{~kg} / \mathrm{m}^{3}$, a jego powierzchnia właściwa od $4600 \mathrm{~cm}^{2} / \mathrm{g}$ do nawet 14000 $\mathrm{cm}^{2} / \mathrm{g}[10,25,26]$. W składzie ziarnowym dominują bardzo drobne ziarna o średnicy poniżej $32 \mu \mathrm{m}$ (około $75 \%$ masy pyłu), a maksymalny wymiar ziarna nie przekracza $300 \mu \mathrm{m}$. 
Table 1. Chemical composition and physical properties of materials used in the experiment

Tabela 1. Sktad chemiczny i wtaściwości fizyczne materiałów użytych $w$ badaniach

\begin{tabular}{|c|c|c|c|}
\hline \multicolumn{2}{|c|}{ Parameter } & $\begin{array}{l}\text { OPC (ordinary Portland cement } \\
\text { CEM I 42.5R) }\end{array}$ & CBPD (Cement by-pass dust) \\
\hline \multirow{12}{*}{ Chemical composition (wt\%) } & Loss on ignition $\left(1100^{\circ} \mathrm{C}\right)$ & 2.67 & 4.85 \\
\hline & CaO & 64.26 & 55.72 \\
\hline & $\mathrm{SiO}_{2}$ & 20.14 & 15.95 \\
\hline & $\mathrm{Al}_{2} \mathrm{O}_{3}$ & 4.22 & 3.13 \\
\hline & $\mathrm{Fe}_{2} \mathrm{O}_{3}$ & 2.25 & 2.04 \\
\hline & $\mathrm{MgO}$ & 2.21 & 1.49 \\
\hline & $\mathrm{SO}_{3}$ & 3.15 & 1.74 \\
\hline & $\mathrm{K}_{2} \mathrm{O}$ & 0.94 & 9.15 \\
\hline & $\mathrm{Na}_{2} \mathrm{O}$ & 0.16 & 0.24 \\
\hline & $\mathrm{Na}_{2} \mathrm{O}_{\mathrm{e}}$ & 0.78 & 6.26 \\
\hline & $\mathrm{Cl}^{-}$ & 0.08 & 5.69 \\
\hline & $\mathrm{CaO}_{\text {free }}$ & 0.01 & 7.96 \\
\hline \multicolumn{2}{|c|}{ Density $\left(\mathrm{k} / \mathrm{m}^{3}\right)$} & 3.15 & 2.42 \\
\hline \multicolumn{2}{|c|}{ Blaine's surface area $\left(\mathrm{cm}^{2} / \mathrm{g}\right)$} & 4050 & 8450 \\
\hline
\end{tabular}

Comparing the chemical compositions of Portland cement and cement bypass dust, it can be seen that the main component of both materials is calcium oxide (Table 1). The content of $\mathrm{CaO}$ in Portland cement is $64.26 \%$. For CBPD the content of $\mathrm{CaO}$ is $55.72 \%$. The free lime content in Portland cement is only $0.01 \%$, but in the case of CBPD is raised to $7.96 \%$ (glycol method). Such high concentration of free lime in CBPD may cause deterioration in properties of cement bypass binders. The free lime reacts with water slowly, much longer than the binding process of cement paste. The lime hydration occurs with a significant change in the volume of hardened cement mortar (lack of volume stability), causing stretching stress in non-plastic cement paste. In consequence, this leads to forming of cracks, and even to destroying of material.

Considerable attention is paid to the high content of alkali oxides in bypass dust. The concentration of alkalis expressed as sodium equivalent $\mathrm{Na}_{2} \mathrm{O}_{e}$ $\left(=\mathrm{Na}_{2} \mathrm{O}+0.658 \cdot \mathrm{K}_{2} \mathrm{O}\right)$ is $6.26 \%$ in bypass dust, whereas in Portland cement $-0.78 \%$. In particular, the content of potassium oxide is very high. The concentration of $\mathrm{K}_{2} \mathrm{O}$ in bypass dust is $9.15 \%$ and is almost 10 times higher than that in Portland cement. Such high proportion of $\mathrm{K}_{2} \mathrm{O}$ may activate the hydraulic properties of bypass dust and, as a result, accelerate the hydration process of cement binder with time.

The characteristic property of bypass dust is high concentration of $\mathrm{Cl}^{-}$ions, at about $5.69 \%$. In used Portland cement the amount of $\mathrm{Cl}^{-}$ions is only $0.08 \%$.
Porównując skład chemiczny cementu portlandzkiego i pyłu z bypassa, można zauważyć, że dominującym składnikiem obu materiałów jest tlenek wapnia (tabela 1). Udział $\mathrm{CaO}$ w cemencie portlandzkim wynosi $64,26 \%$, natomiast w pyle bypass $55,72 \%$. Cement portlandzki zawiera tylko $0,01 \%$ wolnego $\mathrm{CaO}$, podczas gdy w pyle bypass udział wolnego $\mathrm{CaO}$ jest duży $-7,96 \%$ (metoda glikolowa). Tak wysoka koncentracja wolnego $\mathrm{CaO} w$ pyle $\mathrm{z}$ bypassa może wpływać niekorzystnie na właściwości spoiwa cementowego zawierającego $\mathrm{w}$ składzie pył $\mathrm{z}$ bypassa. Hydratacja wapna zachodzi ze znaczną zmianą objętości stwardniałej zaprawy cementowej (brak stałości objętościowej), powodując powstanie naprężeń rozciągających w nieplastycznym zaczynie cementowym. W konsekwencji prowadzi to do powstawania spękań, a nawet może doprowadzić do zniszczenia materiału.

Uwagę zwraca wysoka zawartość alkaliów w pyle bypass. Udział alkaliów w przeliczeniu na ekwiwalent sodowy $\mathrm{Na}_{2} \mathrm{O}_{e}$, określonego wzorem $\mathrm{Na}_{2} \mathrm{O}+0,658 \cdot \mathrm{K}_{2} \mathrm{O}$, wynosi aż $6,26 \% \mathrm{w}$ pyle bypass, natomiast w cemencie portlandzkim - 0,78\%. Zwłaszcza wysoka jest zawartość tlenku potasu. Udział $\mathrm{K}_{2} \mathrm{O}$ w pyle bypass wynosi $9,15 \%$ i jest prawie dziesięciokrotnie większy niż w cemencie portlandzkim. Tak wysoki udział tlenku potasu może aktywować właściwości hydrauliczne pyłu z bypassa, a w konsekwencji przyspieszyć proces hydratacji spoiwa cementowego w czasie.

Cechą charakterystyczną pyłu z bypassa jest wysoki udział jonów chloru, na poziomie 5,69\%. W za- 
In the case of sulphur, the decrease in its concentration is observed for bypass dust, by about $45 \%$ as compared to Portland cement.

The high content of volatile components (including potassium, chlorine and sulfur) in the used bypass dust has a direct impact on the high value of loss on ignition, which value reaches almost $5 \%$.

The results of phase composition of bypass dust, presented in Figure 1, show that the main phase component in dust are: calcite $\left(\mathrm{CaCO}_{3}\right)$, quartz $\left(\mathrm{SiO}_{2}\right)$, sylvine $(\mathrm{KCl})$ and belite $\left(\mathrm{Ca}_{2} \mathrm{SiO}_{4}\right)$, which is agreement with authors [4, 9, 19]. There were also reflections from lime, which confirms the high content of free $\mathrm{CaO}$ in bypass dust (Table 1 ).

\subsection{Experimental methods}

The research tests included four cement binder with the composition given in Table 2. The industrial ordinary Portland cement CEM I 42.5R (the symbol $\mathrm{C} 0$ ) was used as the control cement. The cement binder of $\mathrm{C} 1-\mathrm{C} 3$ were prepared by mixing Portland cement with bypass dust in amount of $0.5 \%, 1 \%$ and $5 \%$ by mass of binder.

\begin{tabular}{|c|c|c|}
\hline Cement sample & OPC & CBPD \\
\hline C0 & 100 & $3 / 4$ \\
C1 & 99.95 & 0.05 \\
C2 & 99.0 & 1.0 \\
C3 & 95.0 & 5.0 \\
\hline
\end{tabular}

The effect of bypass dust on the properties of cement binder such as standard consistency, initial setting time, soundness and compressive strength were analysed. The SEM/EDS observations of cement mortar microstructure are also made.

The standard consistency and initial setting time of cement pastes were carried out according to standard PN-EN 196-3:2016 "Method of testing cement - Part 3: Determination of setting times and soundness". The cement pastes were prepared by mixing of $500 \mathrm{~g}$ of cement and with a predetermined amount of water. The water demand of cement pastes was evaluated when the Vicat plunger penetrated to cement paste to a depth of $6 \pm 2 \mathrm{~mm}$ from the glass plate, on which the Vicat mould with cement paste was placed. Next, the cement paste of standard consistency was penetrated by the Vicat needle, measuring the time from the stosowanym cemencie portlandzkim udział jonów $\mathrm{Cl}^{-}$wynosi tylko $0,08 \%$.

W przypadku siarki obserwujemy spadek jej udziału w pyle z bypassa o około $45 \%$ w porównaniu $\mathrm{z}$ cementem portlandzkim.

Duża zawartość składników lotnych (m.in. potasu, chloru oraz siarki) w zastosowanym pyle cementowym $\mathrm{z}$ bypassa ma bezpośredni wpływ na wysoką wartość straty prażenia, sięgającą prawie $5 \%$.

Wyniki badań składu fazowego pyłu z bypassa, przedstawione na rysunku 1, wskazują, że głównymi składnikami fazowymi pyłu są: węglan wapnia $\left(\mathrm{CaCO}_{3}\right)$, kwarc $\left(\mathrm{SiO}_{2}\right)$, sylwin $(\mathrm{KCl}) \mathrm{i}$ belit $\left(\mathrm{Ca}_{2} \mathrm{SiO}_{4}\right)$. Jest to zgodne z wynikami badań $[4,9,19]$. Stwierdzono również występowanie refleksów od wolnego wapna $(\mathrm{CaO})$, co potwierdza dużą zawartość tego składnika w pyle (tabela 1 ).

\subsection{Metodyka badawcza}

Badania przeprowadzono na czterech spoiwach cementowych o składzie podamy w tabeli 2. Jako cement kontrolny (symbol C0) zastosowano przemysłowy cement portlandzki CEM I 42,5R. Natomiast spoiwa cementowe C1-C3 otrzymano przez wspólne wymieszanie cementu portlandzkiego i pyłu z instalacji bypassa pieca cementowego w ilości 0,5, 1 i 5\% masy spoiwa.

Table 2. Cement mix composition (wt\%) used in the experiment

Tabela 2. Skład spoiw cementowych (mas\%) do badań

Analizowano wpływ pyłu z bypassa na właściwości spoiwa cementowego, takie jak konsystencja normowa, początek czasu wiązania, stałość objętości i wytrzymałość na ściskanie. Wykonano również obserwacje mikrostruktury zaprawy cementowej z wykorzystaniem analizy SEM/EDS.

Badania konsystencji normowej i początku czasu wiązania przeprowadzono zgodnie $\mathrm{z}$ normą PN-EN 196-3:2016 „Metoda badania cementu Część 3: Oznaczanie czasów wiązania i stałości objętości". Przygotowano zaczyny cementowe, mieszając $500 \mathrm{~g}$ cementu z ustaloną wstępnie ilością wody. Zaczyny cementowe wykazały konsystencję normową, gdy bolec aparatu Vicata zanurzył się w zaczynach na głębokość $6 \pm 2 \mathrm{~mm}$ od płytki szklanej, na której umieszczony był $\mathrm{w}$ aparacie pierścień $\mathrm{z}$ zaczynem. Następnie zaczyny o konsystencji normowej podda- 
preparation of cement paste to moment, in which the needle was dipped in the paste to a depth of $6 \pm 3 \mathrm{~mm}$ from the surface of the glass plate. The result was given rounded up to 5 minutes.

The soundness of cement pastes was determined using Le Chatelier moulds according to mentioned standard PN-EN 196-3:2016. The cement paste of standard consistency were prepared and placed in Le Chatelier mould. The mould was kept for 24 hours at temperature of $25^{\circ} \mathrm{C}$ under full humidity condition, and the distance between the end of the needles was measured. Next, the mould was heated to temperature of $100^{\circ} \mathrm{C}$ and maintained at boiling temperature during 3 hours and 5 minutes. After boiling the distance between the end of the needles was again measured. The result was given rounded up to 0.5 minutes.

The compressive strength of cement mortars (standard sand:cement:water in proportion 3:1:0.5) was determined in accordance with standard PNEN 196-1:2016 "Method of testing cement - Part 1: Determination strength". The measurements were carried out on a set of three standard specimens size of $40 \times 40 \times 160 \mathrm{~mm}$. The moulds with fresh mortar were stored for 24 hours in a moist atmosphere. After demoulding the specimens were stored in water. At 2, 28 and 90 days of curing the specimens were removed from the water and subjected to compressive strength tests. The result was given rounded up to $0.01 \mathrm{MPa}$.

The strength measurements were additionally performed for the same cement mortars, but treated in autoclave. The specimens of cement mortar of $40 \times 40 \times 160 \mathrm{~mm}$ size were prepared. The specimens were kept in a moist atmosphere, and next they were demoulded and stored in autoclave at temperature of $180^{\circ} \mathrm{C}$ and pressure of $2 \mathrm{MPa}$. The autoclave was turned off after 12 hours and the specimens were cooled in an autoclave to about $100^{\circ} \mathrm{C}$. Next the specimens were removed from autoclave and cooled 10 minutes with water to approximately $25^{\circ} \mathrm{C}$. The research of compressive strength are performed after 28 and 90 days. The result was given rounded up to $0.01 \mathrm{MPa}$.

The analysis of the microstructure was made on the basis of images obtained from scanning electron microscope (SEM) - FEI Nova NanoSEM 200. The tests were carried out on specimens being pieces of mortar sample after strength test. Samples were sprayed with carbon to ensure sample conductivity. The EDS (Energy Dispersive X-ray Spectroscopy) no próbom penetracji igłą Vicata, mierząc od zarobienia cementu czas, po którym igła zanurzyła się w zaczynach na głębokość $6 \pm 3 \mathrm{~mm}$ od powierzchni płytki szklanej (wynik podano w zaokrągleniu do 5 minut).

Oznaczenie stałości objętości przeprowadzono za pomocą pierścieni Le Chateliera, zgodnie ze wspomnianą normą PN-EN 196-3:2016. Przygotowano zaczyny cementowe o konsystencji normowej, które umieszczano w pierścieniu Le-Chateliera. Pierścień przetrzymywano przez 24 godziny w temperaturze $25^{\circ} \mathrm{C}$ w warunkach pełnej wilgotności, po czym zmierzono odległość pomiędzy igłami pierścienia. Następnie pierścień ogrzewano do temperatury $100^{\circ} \mathrm{C}$, przetrzymując $\mathrm{w}$ temperaturze wrzenia przez 3 godziny i 5 minut. Po gotowaniu ponownie zmierzono odległość pomiędzy końcami igieł. Odległość igieł podano $\mathrm{z}$ dokładnością do $0,5 \mathrm{~mm}$.

Wytrzymałość na ściskanie zapraw cementowych (piasek normowy:cement:woda w proporcji 3:1:0,5) oznaczono według normy PN-EN 196-1:2016 „Metody badania cementu - Część 1: Oznaczanie wytrzymałości". Pomiary były wykonane na trzech beleczkach o wymiarach $40 \times 40 \times 160 \mathrm{~mm}$. Formy ze świeżą zaprawą przechowywano przez 24 godziny w warunkach wilgotnych. Po rozformowaniu beleczki umieszczono w wodzie. Po 2, 28 i 90 dniach dojrzewania beleczki wyjęto $\mathrm{z}$ wody i poddano badaniom wytrzymałości na ściskanie. Wynik badania podano w zaokrągleniu do $0,01 \mathrm{MPa}$.

Pomiary wytrzymałości na ściskanie wykonano dodatkowo dla zapraw cementowych poddanych autoklawizacji. Przygotowano beleczki zapraw o wymiarach $40 \times 40 \times 160 \mathrm{~mm}$, które po 24 godzinach przechowywania $\mathrm{w}$ warunkach wilgotnych rozformowano i przechowywano w autoklawie parowym - zastosowano nasyconą parę wodną o temperaturze $180^{\circ} \mathrm{C}$ i ciśnieniu $2 \mathrm{MPa}$. Po 12 godzinach autoklaw wyłączono i próbki chłodziły się w autoklawie do temperatury około $100^{\circ} \mathrm{C}$. Potem próbki wyjęto i schłodzono wodą do temperatury około $25^{\circ} \mathrm{C}$. Badania wytrzymałości na ściskanie przeprowadzono po 2 i 28 dniach. Wyniki badań wytrzymałości podano w zaokrągleniu do 0,01 MPa.

Analizę mikrostruktury wykonano na podstawie obrazów uzyskanych ze skaningowego mikroskopu elektronowego (SEM) - FEI Nova NanoSEM 200. Badania przeprowadzono na preparatach będących kawałkami próbki zaprawy po badaniu wytrzymałości. Próbki napylono węglem w celu zapewnienia przewodzenia próbki. Wykonano mikroanalizę rentgenowską EDS (Energy Dispersive X-ray Spectro- 
microanalysis was made to identify chemical elements in microareas. The aim of these studies was the analysis the type and morphology of hydrates in cement mortars curing under normal and autoclave conditions.

\section{RESULTS AND DISCUSSION}

\subsection{Standard consistency and initial setting time}

The results of standard consistency (expressed as water demand and w/c ratio) and initial setting time of cement pastes - control (sample $\mathrm{C} 0$ ) and with addition of cement bypass dust (samples C1-C3) are shown in Table 3.

\begin{tabular}{|c|c|c|c|}
\hline \multirow{2}{*}{$\begin{array}{c}\text { Cement } \\
\text { sample }\end{array}$} & \multicolumn{2}{|c|}{ Standard consistency } & \multirow{2}{*}{$\begin{array}{c}\text { Initial setting } \\
\text { time (min) }\end{array}$} \\
\cline { 2 - 3 } & Water demand (g) & w/c (\%) & 195 \\
\hline C0 & 140.7 & 28.1 & 190 \\
C1 & 146.3 & 29.3 & 180 \\
C2 & 149.1 & 29.8 & 175 \\
C3 & 152.9 & 30.6 & \\
\hline
\end{tabular}

The introduction of bypass dust into the cement causes the increase in the water required to obtain cement paste of standard consistency (Table 3 ), which is consistent with the research results in papers [17, $18,27,28]$. The required water demand is increased by $4 \%$ for binder $\mathrm{C} 1$. The higher content of dust in the binder, the higher water demand - the increase in water is $6 \%$ for binder $\mathrm{C} 2$ and almost $9 \%$ for binder C3. It is probably caused by increase in specific surface area of cement binder due to incorporation of bypass dust which, as it is showed in Table 1, is characterized by very high Blaine's surface area of $8450 \mathrm{~cm}^{2} / \mathrm{g}$. An important parameter is also the high loss on ignition of bypass dust, which is about $82 \%$ higher than that for Portland cement. This results in an additional increase in the amount of water required to achieve the binder of standard consistency due to the presence of a large amount of porous grains of unburned carbon with a large specific surface area.

As it is shown in Table 3, the initial setting time of paste $\mathrm{C} 0$ (control cement paste) is 195 minutes. The introduction of bypass dust into the cement shortens the initial setting time of cement paste. The paste $\mathrm{C} 1$ begins to set by 5 minutes earlier than sample $\mathrm{C} 0$. The increase in the content of dust in the binder causes a further shortening of initial setting time, which is consistent with the results in papers $[8,18,29]$. The paste $\mathrm{C} 2$ begins to set after 180 minutes, that is by 15 minutes earlier than paste $\mathrm{C} 0$. The paste $\mathrm{C} 3$ begins to scopy), która pozwoliła na identyfikację pierwiastków chemicznych w mikroobszarach. Celem tych badań była analiza rodzaju i morfologii hydratów w próbkach zapraw dojrzewających w warunkach normalnych i autoklawizacji.

\section{WYNIKI I DYSKUSJA}

\subsection{Konsystencja normowa i początek czasu wiązania}

Wyniki oznaczeń konsystencji normowej (ilość wymaganej wody, stosunek w/c) oraz początku czasu wiązania zaczynów cementowych - kontrolnego (próbka $\mathrm{C} 0$ ) i z dodatkiem pyłu z bypassa (próbki C1C3) - zestawiono w tabeli 3.

Table 3. The standard consistency and initial setting time of cement pastes

Tabela 3. Konsystencja normowa i poczatek czasu wiazania zaczynów cementowych

Wprowadzenie pyłu z bypassa powoduje zwiększenie ilości wody potrzebnej do otrzymania zaczynu o konsystencji normowej (tabela 3), co jest zgodne z wynikami badań publikowanymi w pracach $[17,18$, $27,28]$. Właściwa ilość wody wzrasta o $4 \%$ dla spoiwa C1. Im większy udział pyłu w spoiwie, tym większe zapotrzebowanie na wodę - wzrost ilości wody wynosi $6 \%$ dla spoiwa $\mathrm{C} 2$ i prawie $9 \%$ dla spoiwa $\mathrm{C} 3$. Jest to prawdopodobnie spowodowane wzrostem powierzchni właściwej spoiwa wskutek wprowadzenia dojego składu pyłu, który,jak przedstawiono w tabeli 1, charakteryzuje się wysoką powierzchnią Blaine'a, na poziomie $8450 \mathrm{~cm}^{2} / \mathrm{g}$. Istotnym parametrem są również wysokie straty prażenia pyłu z bypassa, które są o około $82 \%$ wyższe niż dla cementu portlandzkiego. Powoduje to dodatkowy wzrost ilości wody wymaganej do osiągnięcia konsystencji normowej spoiwa z powodu obecności dużej ilości porowatych ziaren niespalonego węgla o dużej powierzchni właściwej.

Jak pokazano w Tabeli 3, początek czasu wiązania zaczynu C0 wynosi 195 minuty. Wprowadzenie pyłu z bypassa powoduje skrócenie początku czasu wiązania zaczynu cementowego. Zaczyn $\mathrm{C} 1$ zaczyna wiązać o 5 minut wcześniej niż próbka C0. Wzrost udziału pyłu w spoiwie powoduje dalsze skrócenie początku czasu wiązania. Podobne wyniki uzyskano w pracach $[8,18,29]$. Zaczyn C2 zaczyna wiązać po 180 minutach, czyli o 15 minut wcześniej niż zaczyn C0. Natomiast zaczyn C3 zaczyna wiązać już po 175 
set after 175 minutes, about 20 minutes earlier than control cement paste. This fact can be explained by the high content of alkalis in bypass cement binders, which in turn may activate hydration of cement fraction (mainly alite $-\mathrm{C}_{3} \mathrm{~S}$ ) $[17,30]$.

\subsection{Soundness}

The soundness results of cement pastes by method Le Chatelier are presented in Table 4.

The introduction of bypass dust into the cement

\begin{tabular}{|c|c|}
\hline Cement sample & Soundness $(\mathbf{m m})$ \\
\hline C0 & 2 \\
C1 & 3 \\
C2 & 5 \\
C3 & 6 \\
\hline
\end{tabular}

causes greater volume changes of cement paste, measured as distance between the end of the needles of Le Chatelier mould before and after cooking of cement paste. The greater volume changes of pastes C1-C3 should be explained by the higher content of free lime $(\mathrm{CaO})$ in these cement pastes due to incorporation of bypass dust to binders $\mathrm{C} 1-\mathrm{C} 3$. The content of free $\mathrm{CaO}$ in bypass dust is 7-times higher than that in Portland cement (Table 1). The molar volume of $\mathrm{CaO}$ and $\mathrm{Ca}(\mathrm{OH})_{2}$ is respectively 16.76 and $33.06 \mathrm{~cm}^{3} / \mathrm{mol}$.

The higher concentration of bypass dust in cement binder, the greater expansion of needles of Le Chatelier mould. For paste $\mathrm{C} 3$, the volume change is $6 \mathrm{~mm}$ (Table 4). Taking into account the content of free lime in Portland cement and bypass dust (Table 1), the calculated amount of free $\mathrm{CaO}$ in paste $\mathrm{C} 3$ is $0.41 \%$.

The results show that all analysed binders containing bypass dust in amount up to $5 \%$ by mass of binder keep volume stability according to requirements of standard PN-EN 197-1:2012. The Le Chatelier test does not exceed allowed value of $10 \mathrm{~mm}$. This is confirmed with research results [11].

\subsection{Compressive strength under normal water curing}

The results of compressive strength of cement mortars are presented in Table 5. The cement bypass dust negative influences on the strength of cement mortars. The strengths of mortars $\mathrm{C} 1-\mathrm{C} 3$ is lower than minutach, o 20 minut wcześniej niż zaczyn kontrolny. Fakt ten można wytłumaczyć wysoką zawartością alkaliów w spoiwach zawierających pył z bypassa, co z kolei może aktywować proces hydratacji cementu (głównie alitu-C3S) [17, 30].

\subsection{Stałość objętości}

Wyniki badań stałości objętości zaczynów cementowych, według metody Le-Chateliera, przedstawiono w tabeli 4.

Table 4. The soundness of cement pastes (Le-Chatelier method)

Tabela 4. Stałość objętości zaczynów cementowych (metoda Le-Chateliera)

Dodatek pyłu z bypassa powoduje większe zmiany objętościowe zaczynu cementowego, mierzone jako odległość pomiędzy końcami igieł pierścienia Le-Chateliera przed i po gotowaniu zaczynu. Większe zmiany objętościowe zaczynów C1-C3 należy thumaczyć większą zawartością wolnego wapna $(\mathrm{CaO})$ w tych zaczynach wskutek obecności pyłu z bypassa w składzie spoiw $\mathrm{C} 1-\mathrm{C} 3$. Udział wolnego $\mathrm{CaO}$ w pyle bypass jest 7-krotnie większy niż w cemencie portlandzkim (Tabela 1). Objętość molowa $\mathrm{CaO}$ wynosi $16,76 \mathrm{~cm}^{3} / \mathrm{mol}$, natomiast objętość molowa $\mathrm{Ca}(\mathrm{OH})_{2}-33,06 \mathrm{~cm}^{3} / \mathrm{mol}$.

Im większy udział pyłu z bypassa w spoiwie, tym większa rozszerzalność igieł pierścienia Le-Chateliera. W przypadku zaczynu C3 zmiana objętości wynosi $6 \mathrm{~mm}$ (tabela 4). Biorąc pod uwagę zawartość wolnego $\mathrm{CaO}$ w cemencie portlandzkim i pyle (tabela 1), obliczona zawartość wolnego $\mathrm{CaO}$ w zaczynie $\mathrm{C} 3$ wynosi $0,41 \%$.

Wyniki badań wskazują, że wszystkie analizowane spoiwa zawierające pył $\mathrm{z}$ bypass $\mathrm{w}$ ilości do $5 \%$ zachowują stałość objętości zgodnie z wymaganiami normy PN-EN 197-1:2012 „Cement - Część 1: Skład, wymagania i kryteria zgodności dotyczące cementów powszechnego użytku". Próba Le Chateliera nie przekracza dopuszczalnych $10 \mathrm{~mm}$. Jest to zgodne z wynikami badań [11].

\subsection{Wytrzymałość na ściskanie w normalnych warunkach dojrzewania}

Wyniki badań wytrzymałości na ściskanie zapraw cementowych przedstawiono $\mathrm{w}$ tabeli 5 . Pył $\mathrm{z}$ bypassa wpływa negatywnie na wytrzymałość zapraw 
that of mortar $\mathrm{C} 0$ after each analyzed period. This is due to lower fraction of Portland cement in all bypass cement binder (so-called "dissolution effect"), that is, the component, which is responsible for hydration process.

\begin{tabular}{|c|c|c|c|}
\hline \multirow{2}{*}{$\begin{array}{c}\text { Cement } \\
\text { sample }\end{array}$} & \multicolumn{3}{|c|}{ Compressive strength (MPa) after: } \\
\cline { 2 - 4 } & 2 days & 28 days & 90 days \\
\hline C0 & $30.91 \pm 0.11$ & $54.32 \pm 0.09$ & $56.26 \pm 0.06$ \\
C1 & $30.14 \pm 0.18$ & $53.77 \pm 0.26$ & $55.98 \pm 0.13$ \\
C2 & $29.72 \pm 0.23$ & $53.19 \pm 0.14$ & $54.33 \pm 0.15$ \\
C3 & $32.62 \pm 0.26$ & $52.69 \pm 0.21$ & $50.02 \pm 0.08$ \\
\hline
\end{tabular}

The decrease in compressive strength of mortars C1-C3 may be also caused by higher content of free $\mathrm{CaO}$ in binder $\mathrm{C} 1-\mathrm{C} 3$ due to introduction of bypass dust, which represents the high concentration of free $\mathrm{CaO}$ (Table 1). Taking into account the content of bypass dust (Table 2), the calculated amount of free $\mathrm{CaO}$ in samples $\mathrm{C} 1, \mathrm{C} 2$ and $\mathrm{C} 3$ is respectively $0.01 \%$, $0.09 \%$ and $0.41 \%$. Although the free lime rapidly hydrates, the $\mathrm{Ca}(\mathrm{OH})_{2}$ exhibits lower strength, which negatively affects the mechanical properties of the final product.

The cement binder containing bypass dust requires greater more water to obtain cement paste of standard consistency, which in results may lead to increase in microporosity of cement paste, especially the increase in content of capillary pores and macropores in microstructure [18]. In turn, the increase in microporosity adversely affects the strength properties of the mortar (less resistance to the compressive forces).

According to Table 5, after 2 days the compressive strength of all cement binders exceed $20 \mathrm{MPa}$. For mortar $\mathrm{C} 1$ and $\mathrm{C} 2$, the decrease in mortar strength is respectively only $2 \%$ and $4 \%$ as compared to that of control mortar $\mathrm{C} 0$. In the case of mortar $\mathrm{C} 3$, the increase in strength is observed and the difference is about $6 \%$ comparing to sample $\mathrm{C} 0$.

This increase in early strength of mortar $\mathrm{C} 3$ may be due to higher content of alkalis in binder $\mathrm{C} 3$, which may activate hydration process of cement by forming an additional amount of C-S-H in the hydrating system [31]. However, it should be remembered that the total content of alkalis in the cement binder with bypass dust should not exceed $0.6 \%$, when the aggregate rich in reactive silica is used. Taking into account the concentration of bypass dust (Table 2), the amount cementowych. Wytrzymałość zapraw C1-C3 jest mniejsza niż zaprawy kontrolnej C0 po każdym okresie badań. Jest to spowodowane mniejszym udziałem cementu portlandzkiego w tych spoiwach (tzw. ,efekt rozcieńczenia"), a więc składnika, który odpowiada za szybkość procesu hydratacji.

Table 5. The compressive strength of cement mortars hardened at normal conditions (water $-25^{\circ} \mathrm{C}$ )

Tabela 5. Wytrzymałość na ściskanie zapraw cementowych twardniejacych $w$ warunkach normalnych (woda $-25^{\circ} \mathrm{C}$ )

Spadek wytrzymałości na ściskanie zapraw C1-C3 może być również spowodowany wysokim udziałem wolnego $\mathrm{CaO}$ w spoiwach $\mathrm{C} 1-\mathrm{C} 3$ na skutek wprowadzenia do składu cementu pyłu z bypassa, który wykazuje wysoką zawartość wolnego $\mathrm{CaO}$ (tabela 1). Biorąc pod uwagę ilość wprowadzonego dodatku (tabela 2), obliczona wartość niezwiązanego $\mathrm{CaO}$ w próbkach $\mathrm{C} 1, \mathrm{C} 2$ i C3 wynosi odpowiednio 0,01\%, $0,09 \%$ i $0,41 \%$. Choć wolne wapno ulega gwałtownej hydratacji, to jednak $\mathrm{Ca}(\mathrm{OH})_{2}$ wykazuje mniejszą wytrzymałość, co negatywnie wpływa na właściwości mechaniczne produktu finalnego.

Spoiwo cementowe zawierające pył $\mathrm{z}$ bypassa w składzie wymaga większej ilości wody, aby otrzymać zaczyn cementowy o konsystencji normowej, co w rezultacie może prowadzić do wzrostu mikroporowatości zaczynu, zwłaszcza wzrostu zawartości porów kapilarnych i makroporów w mikrostrukturze [18]. Z kolei wzrost mikroporowatości wpływa niekorzystnie na cechy wytrzymałościowe zaprawy (mniejszy opór jaki siłom ściskającym stawia materiał).

Jak przedstawiono w tabeli 5, po dwóch dniach wytrzymałość na ściskanie wszystkich zapraw cementowych przekracza $20 \mathrm{MPa}$. W przypadku zapraw $\mathrm{C} 1$ i C2, spadek wytrzymałości wynosi odpowiednio tylko $2 \%$ i $4 \% \mathrm{w}$ stosunku do wytrzymałości zaprawy kontrolnej C0. Z kolei w przypadku zaprawy C3 obserwuje się wzrost wytrzymałości, a różnica wynosi około $6 \% \mathrm{w}$ porównaniu z zaprawą C0. Wzrost wytrzymałości wczesnej zaprawy C3 może być wynikiem dużego udziału alkaliów w spoiwie C3, które mogą aktywować proces hydratacji cementu z utworzeniem dodatkowej ilości C-S-H w hydratyzującym układzie [31]. Należy jednak pamiętać, że całkowita zawartość alkaliów $\mathrm{w}$ cemencie $\mathrm{z}$ dodatkiem pyłu $\mathrm{z}$ bypassa nie powinna przekraczać $0,6 \% \mathrm{w}$ przypad- 
of $\mathrm{K}_{2} \mathrm{O}$ and $\mathrm{Na}_{2} \mathrm{O}$ in binder $\mathrm{C} 3$ is respectively 1.36 and $0.16 \%$, which gives total alkalis content of $1.06 \%$ $\mathrm{Na}_{2} \mathrm{O}_{e}$.

It is clear that with curing time the compressive strength of all cement mortars is increased as a consequence of hydration process proceeding. After 28 days, the decrease in compressive strength of mortars $\mathrm{C} 1$ and $\mathrm{C} 2$ is comparable and the difference in comparison to strength of mortar $\mathrm{C} 0$ do not exceed $2 \%$ (Table 5). For mortar $\mathrm{C} 3$, the decrease in strength is raised to $7 \%$. The significant decrease in strength of mortar C3 may be due to a significant change in volume of this mortar, and the factor influencing the change in volume is the hydration of free $\mathrm{CaO}$. After 90 days, the strength of mortars $\mathrm{C} 0, \mathrm{C} 1$ and $\mathrm{C} 2$ is in the range of 54-56 MPa, whereas the strength of mortar $\mathrm{C} 3$ is only about $50 \mathrm{MPa}$ with difference of $11 \%$ in comparison to mortar C0 (Table 5).

The results in Table 5 show that the incorporation up to $1 \%$ cement bypass dust to the cement can obtain cement of strength class $42.5 \mathrm{R}$ according to PN-EN 197-1:2012, equal to reference cement (CEM I 42.5R) used in the experiment. For addition of $5 \%$ bypass dust, the cement of strength class $32.5 \mathrm{R}$ is obtained.

\subsection{Compressive strength of autoclaved cement mortars}

In this studies, the control cement binder (sample $\mathrm{C} 0$ ) and cement binder containing the highest amount of bypass dust (sample $\mathrm{C} 3-5 \%$ of bypass dust) were used. The autoclaving process were performed in temperature of $180^{\circ} \mathrm{C}$ and pressure of $2 \mathrm{MPa}$ for 12 hours. After autoclaving the mortar were stored in the water until to compressive strength test. The results are presented in Table 6 .

\begin{tabular}{|c|c|c|}
\hline \multirow{2}{*}{ Cement sample } & \multicolumn{2}{|c|}{ Compressive strength (MPa) after: } \\
\cline { 2 - 3 } & $\mathbf{2}$ days & $\mathbf{2 8 ~ d a y s}$ \\
\hline C0 & $50.05 \pm 0.16$ & $64.85 \pm 0.21$ \\
C3 & $55.60 \pm 0.18$ & $69.85 \pm 0.09$ \\
\hline
\end{tabular}

After 2 days, the compressive strength of all autoclaved cement mortars exceeds $50 \mathrm{MPa}$. In the case of mortar $\mathrm{C} 3$, the increase in strength is $11 \%$ in respect to control mortar $\mathrm{C} 0$. Compared to normal curing conditions, the increase in 2-day compressive strength of autoclaved mortar $\mathrm{C} 0$ is $62 \%$. For mortar $\mathrm{C} 3$, the autoclaving process provides greater increase in compressive strength, up to $55.60 \mathrm{MPa}$, and the difference is $87 \%$ in relation to normal conditions. ku, gdy stosowane jest kruszywo bogate w reaktywną krzemionkę. Biorąc pod uwagę udział pyłu z bypassa (tabela 2), udział tlenków $\mathrm{K}_{2} \mathrm{O}$ i $\mathrm{Na}_{2} \mathrm{O}$ w spoiwie $\mathrm{C} 3$ wynosi odpowiednio $1,36 \%$ i $0,16 \%$, co daje łączną zawartość alkaliów wynoszącą 1,06\% $\mathrm{Na}_{2} \mathrm{O}_{e}$.

Jest oczywiste, że wraz z upływem czasu wytrzymałość na ściskanie wszystkich badanych zapraw cementowych wzrasta w wyniku postępującego procesu hydratacji. Po 28 dniach spadek wytrzymałości na ściskanie zapraw $\mathrm{C} 1$ i $\mathrm{C} 2$ jest porównywalny i nie przekracza $2 \% \mathrm{w}$ stosunku do zaprawy $\mathrm{C} 0$ (tabela 5). Natomiast w przypadku zaprawy C3, różnica wytrzymałości wzrasta do 7\%. Znaczny spadek wytrzymałości zaprawy C3 jest efektem znacznej zmiany objętości, a czynnikiem wpływającym na zmiany objętości jest hydratacja wolnego CaO. Po 90 dniach, wytrzymałość zapraw C0, C1 i C2 mieści się w zakresie 54-56 MPa, podczas gdy wytrzymałość zaprawy C3 wynosi tylko $50 \mathrm{MPa}$, co daje spadek o $11 \%$ w stosunku do zaprawy C0 (tabela 5).

Wyniki przedstawione w Tabeli 5 wskazują, że wprowadzenie do składu cementu pyłu z bypassa w ilości do $1 \%$ pozwala uzyskać cement klasy 42,5R zgodnie z normą PN-EN 197-1:2012, a więc takiej samej klasy jak cement kontrolny (CEM I 42,5R) zastosowany w badaniach. Przy dodatku 5\% pyłu z bypassa można uzyskać cement o klasie wytrzymałości 32,5R.

\subsection{Wytrzymałość na ściskanie w warunkach autoklawizacji}

W badaniach wykorzystano spoiwo kontrolne (próbka C0) i spoiwo zawierające w składzie najwięcej pyłu z bypassa (próbka $\mathrm{C} 3-5 \%$ pyłu). Wyniki badań wytrzymałości po 2 i 28 dniach zestawiono w tabeli 6 .

Table 6. The compressive strength of autoclaved cement mortars $\left(2 \mathrm{MPa}-180^{\circ} \mathrm{C}\right)$ after 2 and 28 days of hardening Tabela. 6. Wytrzymatość na ściskanie autoklawizowanych zapraw cementowych $\left(2 \mathrm{MPa}-180^{\circ} \mathrm{C}\right)$ po 2 i 28 dniach twardnienia

Po dwóch dniach wytrzymałość na ściskanie zapraw cementowych poddanych procesowi autoklawizacji przekracza $50 \mathrm{MPa}$. W przypadku zaprawy C3 obserwuje się wzrost wytrzymałości o 11\% w stosunku do zaprawy kontrolnej $\mathrm{C} 0$. W porównaniu do normalnych warunków dojrzewania, wzrost wytrzymałości dwudniowej autoklawizowanej zaprawy C0 wynosi $62 \%$. W przypadku próbki C3 proces autoklawizacji zapewnia większy wzrost wytrzymałości 
After 28 days, the increase in compressive strength of autoclaved mortar C0 is $19 \%$ as compared to the same mortar, but cured under normal conditions. In the case of autoclaved mortar $\mathrm{C} 3$, the difference in strength gain is $32 \%$ (compressive strength is increased to $69.85 \mathrm{MPa}$ ). The higher increase in compressive strength of autoclaved mortar C3 may be caused by the formation of large amounts of hydrated calcium silicates with a higher degree of crystallization, such as tobermorite.

The autoclaving increases the compressive strength of cement mortar, and the presence of bypass dust has a positive effect on the mortar strength compared to Portland cement mortar. This means that the bypass dust can be used as a raw material for the production of autoclaved aerated concrete.

\subsection{Microstructure of standard and autoclaved cement mortars}

The possibility of use of cement bypass dust for production of aerated autoclaved concrete (AAC) was analysed in paper [32]. The authors [32] showed that main hydration products in ACC are: poorly crystallized C-S-H gel and highly crystalline $11 \AA$ tobermorite (autoclaving process at temperature of $100^{\circ} \mathrm{C}$ ). It was also confirmed by research results [33-36]. In turn, the studies [34] showed that anhydrite, hydrogranates and small amounts of minerals such as quartz and calcite may be formed in AAC with addition of CBPD.

The compressive strength of AAC is increased, when much more crystalline forms such as C-S-H, tobermorite and hydrogarnets (well crystallized and stable crystalline structure) are observed $[35,36]$.

The paper presents only the results of the SEM/EDS analysis of the microstructure of hardened mortar C3, which contains the most bypass, at the level of $5 \%$ by mass of binder.

The microstructure images of mortar $\mathrm{C} 3$ cured in normal conditions are showed in Figures 2 and 3. The microstructure images of autoclaved mortar $\mathrm{C} 3$ after 28 days are given in Figures 4 and 5. na ściskanie, do poziomu $55,60 \mathrm{MPa}$, a więc o $87 \%$ większy niż w warunkach normalnych.

Po 28 dniach wzrost wytrzymałości na ściskanie autoklawizowanej zaprawy C0 wynosi 19\% w stosunku do wytrzymałości zaprawy dojrzewającej w warunkach normalnych. Natomiast w przypadku autoklawizowanej zaprawy C3 różnica w przyroście wytrzymałości wynosi 32\% (wytrzymałość na ściskanie wzrasta do poziomu $69,85 \mathrm{MPa}$ ). Większy przyrost wytrzymałości na ściskanie zaprawy $\mathrm{C} 3$ po autoklawizacji może być spowodowany tworzeniem się dużych ilości uwodnionych krzemianów wapnia o wyższym stopniu wykrystalizowania, takich jak tobermoryt.

Autoklawizacja zwiększa wytrzymałość na ściskanie zaprawy cementowej, a obecność pyłu z bypassa wpływa korzystnie na wytrzymałość zaprawy w stosunku do zaprawy z cementu portlandzkiego. Oznacza to, że pył z bypassa może być stosowany jako surowiec do produkcji autoklawizowanego betonu komórkowego.

\subsection{Mikrostruktura zapraw cementowych dojrzewających w warunkach normalnych oraz po procesie autoklawizacji}

Możliwość wykorzystania pyłu z bypassa pieca cementowego do wytwarzania autoklawizowanego betonu komórkowego (ABK) analizowano w pracy [32]. Wykazano, że głównymi produktami hydratacji ABK są: słabo wykrystalizowany żel C-S-H oraz wysokokrystaliczna odmiana tobermorytu $11 \AA$ (autoklawizacja przy temperaturze $100^{\circ} \mathrm{C}$ ). Potwierdziły to również wyniki badań [33-36]. Z kolei badania [34] wskazały, że w ABK z dodatkiem CBPD mogą tworzyć się również anhydryt, hydrogranaty oraz niewielkie ilości minerałów takich jak kwarc i kalcyt.

Wytrzymałość na ściskanie ABK wzrasta, gdy obserwuje się znacznie więcej form krystalicznych takich jak C-S-H, tobermoryt i hydrogranaty (dobrze wykrystalizowana i stabilna struktura krystaliczna) [35, 36].

$\mathrm{W}$ pracy zaprezentowano jedynie wyniki analizy SEM/EDS mikrostruktury stwardniałej zaprawy C3, która zawiera w składzie najwięcej pyłu z bypassa, na poziomie $5 \%$ masy spoiwa.

Zdjęcia mikrostruktury zaprawy C3 dla normalnych warunków dojrzewania zestawiono na rysunkach 2 i 3. Natomiast zdjęcia mikrostruktury autoklawizowanej zaprawy C3 po 28 dniach pokazano na rysunkach 4 i 5. 

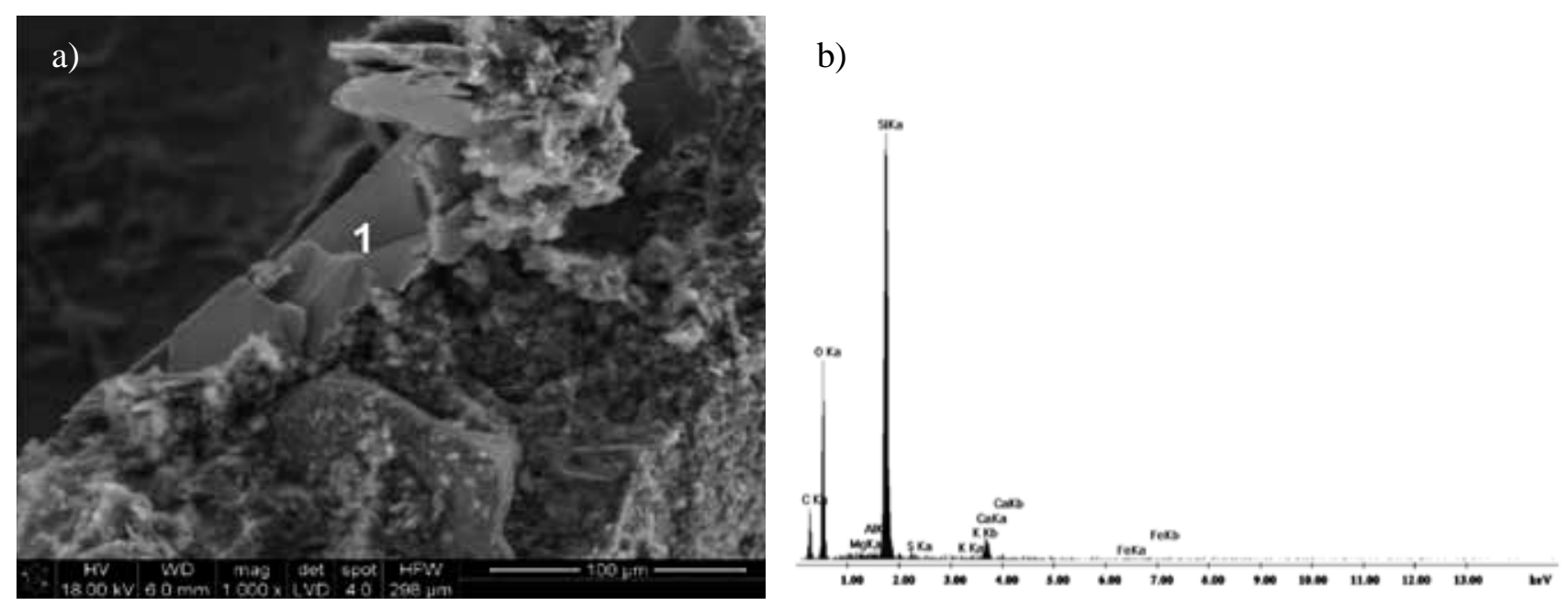

Fig. 2. The microstructure of moratr $C 3$ after 28 days of hardening in normal condition (water) with visible Portlandite crystalis (point 1): a) SEM. Modification of $10000 x$; b) EDS in point 1

Rys. 2. Mikrostruktura zaprawy C3 po 28 dniach twardnienia w warunkach normalnych (woda) z widocznymi kryształami portlandytu (punkt 1): a) SEM. Powiększenie 1000x; b) EDS w punkcie 1
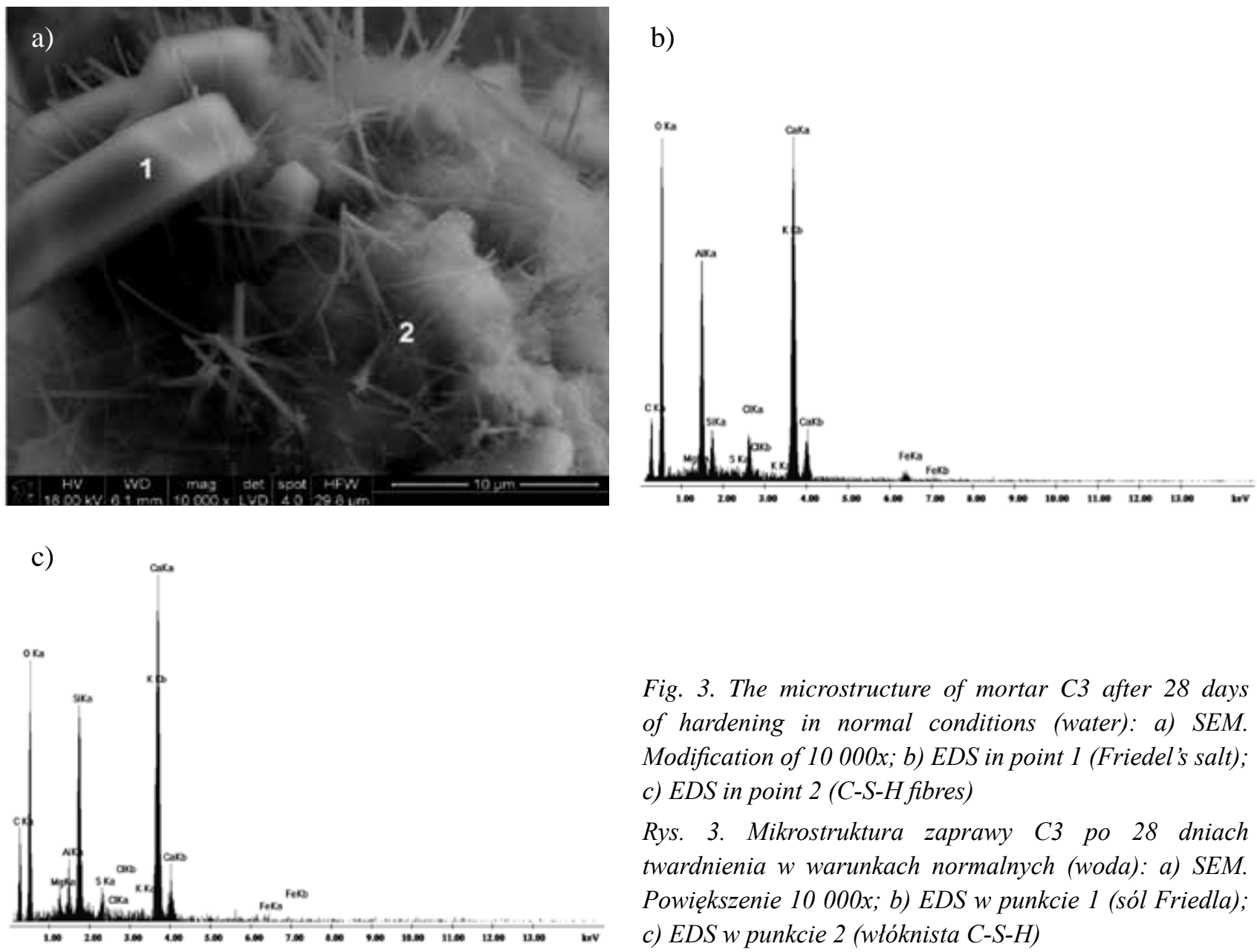

Fig. 3. The microstructure of mortar C3 after 28 days of hardening in normal conditions (water): a) SEM. Modification of $10000 x$; b) EDS in point 1 (Friedel's salt); c) EDS in point 2 (C-S-H fibres)

Rys. 3. Mikrostruktura zaprawy C3 po 28 dniach twardnienia $w$ warunkach normalnych (woda): a) SEM. Powiększenie 10 000x; b) EDS w punkcie 1 (sól Friedla); c) EDS w punkcie 2 (wtóknista $C-S-H$ ) 

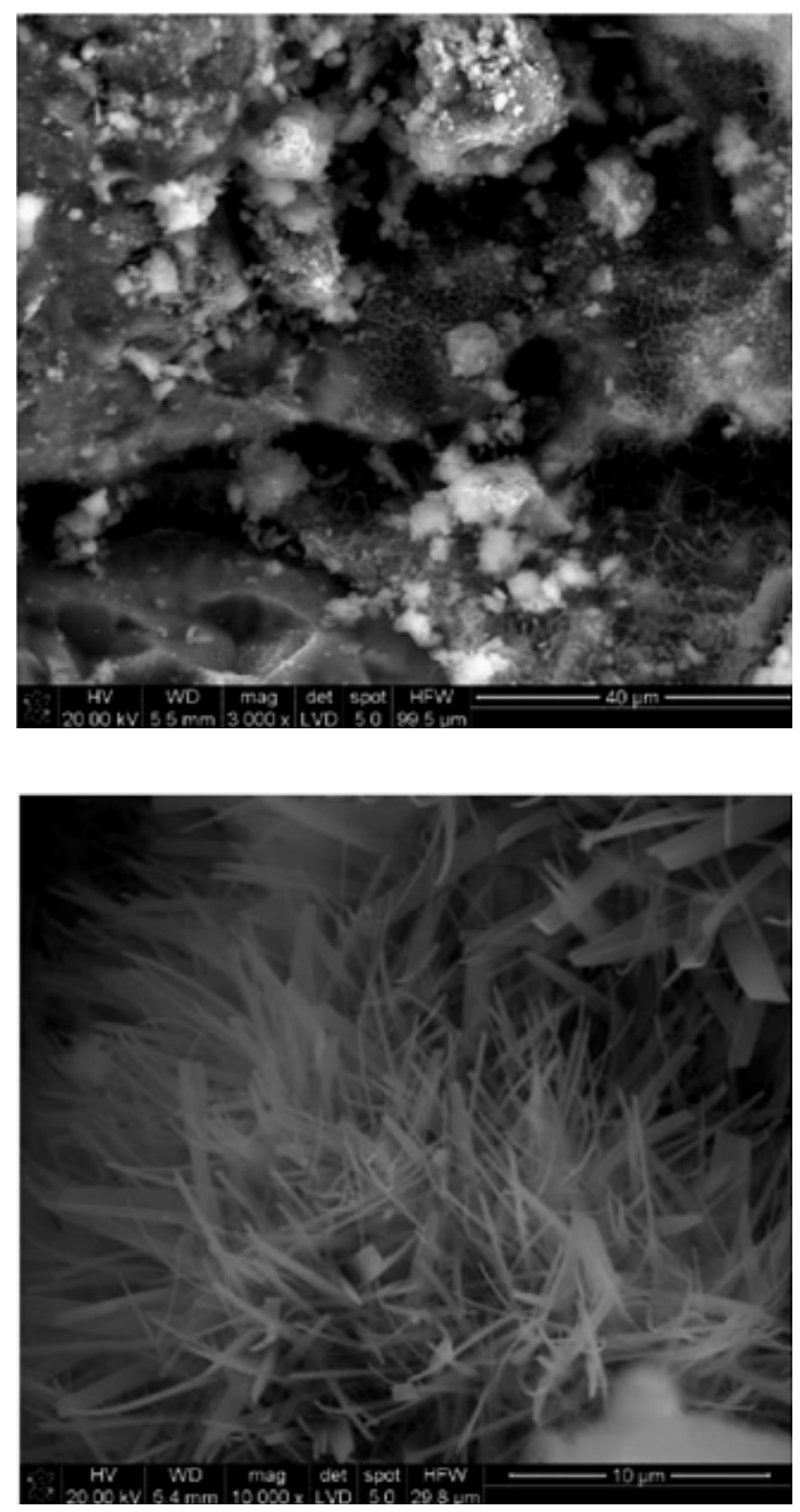

Fig. 4. The tobermorite fibres in autoclaved mortar C3 after 28 days of hardening in normal conditions (water). SEM. Modification of $3000 x$

Rys. 4. Wtókna tobermorytu w autoklawizowanej zaprawie C3 po 28 dniach twardnienia $w$ warunkach normalnych (woda). SEM. Powiększenie 3000x

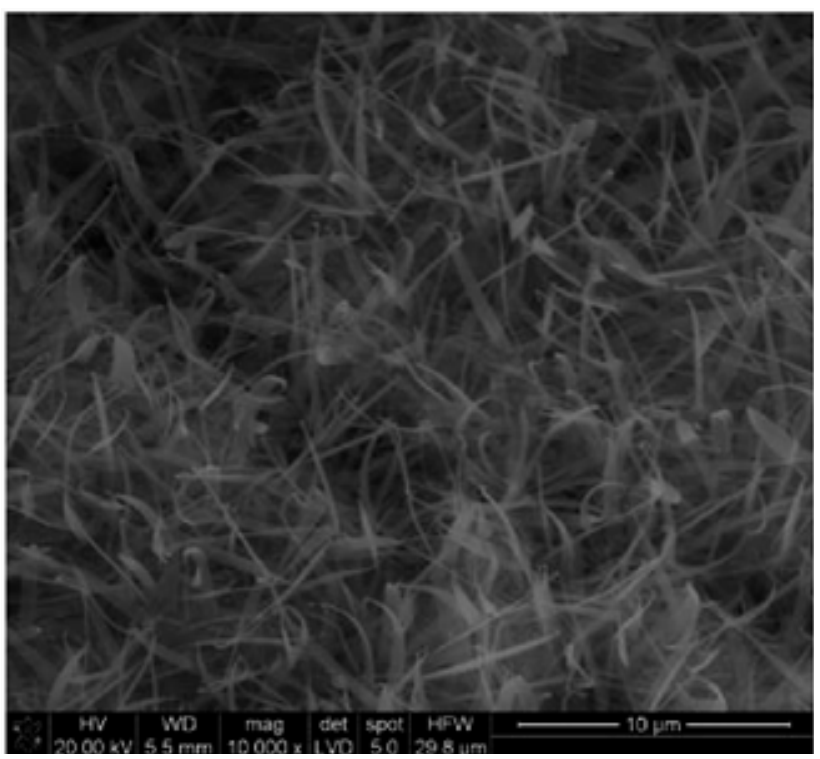

Fig. 5. The C-S-H gel phase and tobermorite fibres (right-centre part of the figure) in autoclaved mortar C3 after 28 days of hardening in normal conditions (water). SEM. Modification of $10000 x$

Fig. 5. Żelowa faza C-S-H oraz wtókna tobermorytu (prawa środkowa część rysunku) w autoklawizowanej zaprawie C3 po 28 dniach twardnienia w warunkach normalnych (woda). SEM. Powiększenie $10000 x$

The main hydration product in mortar $\mathrm{C} 3$, cured in standard and autoclaved conditions is C-S-H gel. The well-formed hexagonal Portlandite crystals are also visible (point 1 in Figure 2), confirming the cement hydration progression. After 28 days, the crystals of Friedel's salt and fibrous C-S-H are determined in mortar C3 (Figure 3).

After 28 days, in the microstructure of autoclaved mortar C3 the large amounts of tobermorite (wellformed needles) are visible (Figure 4), as well as the C-S-H phase with a higher degree of crystallization
Głównym produktem hydratacji w zaprawie cementowej C3, dojrzewającej w warunkach normalnych i w autoklawie, jest żelowa faza C-S-H. Widoczne są również dobrze wykształcone heksagonalne kryształy Portlandytu (punkt 1 na rysunku 2), co potwierdza postępujący proces hydratacji spoiwa C3. Po 28 dniach w mikrostrukturze zaprawy C3 stwierdza się obecność kryształów soli Friedela, a także fazy C-S-H w formie włókien (rysunek 3).

Po 28 dniach w mikrostrukturze autoklawizowanej zaprawy C3 widoczne są duże ilości tobermorytu 
(Figure 5). This confirms results presented in papers [32-36]. The fibres of tobermorite are located between grains of cements, which, as a consequence, leads to increased tightness of mortar $\mathrm{C} 3$ (decrease in microporosity) in comparison to control mortar $\mathrm{C} 0$.

The SEM/EDS results confirm that for cement binder containing up to $5 \%$ of cement bypass dust as replacement of ordinary Portland cement CEM I $42.5 \mathrm{R}$ in binder, it is possible to obtain tobermorite phase in specified hydrothermal conditions (in temperature of $180^{\circ} \mathrm{C}$ and at pressure of $2 \mathrm{MPa}$ for 12 hours). Thus, the binder $\mathrm{C} 3$ used in the experiment may be utilized as material in production of autoclaved aerated concrete.

\section{CONCLUSIONS}

The application of cement bypass to the cement binder increases the water demand for standard consistency and prolongs the initial setting time of cement binder as compared to Portland cement without bypass dust. For analysed binders containing 0.5, 1 and $5 \%$ bypass dust, the amount of water required for full cement hydration is increased respectively by about $4 \%, 6 \%$ and $9 \%$ as compared to control cement. The higher content of dust in binder, the cement paste begins to set faster. The cement paste containing 5\% bypass dust begins to set by 20 minutes earlier than control cement paste.

Despite the significant amount of free $\mathrm{CaO}$ in dust, the all analysed cement paste containing bypass dust, determined by Le Chatelier method, does not exceed $10 \mathrm{~mm}$ in accordance with requirements of standard PN-EN 197-1.

The early (2-day) compressive strength of cement mortar containing 0.5 and $1 \%$ bypass dust is comparable to that of Portland cement. The strength of these mortars is decreased only by $4 \%$ and $6 \%$, respectively. This is due to lower fraction of Portland cement CEM I 42.5R in these binders (so-called "dissolution effect"). For cement containing 5\% dust, the increase in strength is observed, and the difference is about $6 \%$ as compared to Portland cement. This is probably due to activation of cement hydration as a result of introduction of greater amount of alkalis to cement binder (the highest content of bypass dust in this binder) compared to other mortars, especially comparison to reference mortar.

After 28 days, the all cement mortars containing bypass dust represent lower compressive strength than Portland cement. This may be a consequence of the increase in the content of free $\mathrm{CaO}$ in cements w postaci dobrze wykształconych igieł (rys. 4), jak również faza C-S-H o wyższym stopniu wykrystalizowania (rys. 5). Potwierdza to wyniki badań zawarte w pracach [32-36]. Włókna tobermorytu znajdują się w przestrzeni pomiędzy ziarnami cementu (rys. 5), co w efekcie prawdopodobnie prowadzi do wzrostu szczelności zaprawy C3 (spadku mikroporowatości) w porównaniu do zaprawy kontrolnej $\mathrm{C}$.

Badania SEM/EDS potwierdzają, że dla spoiwa zawierającego do $5 \%$ pyłu z bypassa jako zamiennika składnika cementowego CEM I 42,5R w spoiwie, powstaje tobermoryt przy zastosowanych parametrach autoklawizacji (temperatura $180^{\circ} \mathrm{C}$ i ciśnienie $2 \mathrm{MPa}$ przez 12 godzin). Zatem spoiwo C3, które zastosowano w eksperymencie, może być zastosowane jako materiał $\mathrm{w}$ procesie produkcji autoklawizowanego betonu komórkowego.

\section{PODSUMOWANIE}

Wprowadzenie pyłu z instalacji bypassa pieca cementowego zwiększa ilość wody wymaganej do uzyskania zaczynu cementowego o konsystencji normowej oraz wydłuża początek czasu wiązania spoiwa cementowego w stosunku do spoiwa na bazie cementu portlandzkiego bez dodatku. W przypadku badanych spoiw zawierających $0,1 \%, 1 \%$ i $5 \%$ pyłu z bypassa, ilość wody niezbędnej do pełnej hydratacji spoiwa wzrasta odpowiednio o około 4, 6 i 9\% w stosunku do cementu kontrolnego. Im większy udział pyłu w mieszance, tym zaczyn cementowy zaczyna szybciej wiązać. Zaczyn cementowy zawierający $5 \%$ pyłu z bypassa zaczyna wiązać o 20 minut wcześniej niż zaczyn z cementu kontrolnego.

Mimo znacznej zawartości wolnego $\mathrm{CaO}$ w pyle, rozszerzalność liniowa wszystkich badanych zaczynów $\mathrm{z}$ dodatkiem pyłu $\mathrm{z}$ bypassu, mierzona metodą Le Chateliera, nie przekracza $10 \mathrm{~mm}$ zgodnie z wymaganiami normy PN-EN 197-1.

Wczesna (dwudniowa) wytrzymałość na ściskanie zaprawy cementowej zawierającej 0,5 i $1 \%$ pyłu z bypassa jest porównywalna $\mathrm{z}$ wytrzymałością zaprawy z cementu portlandzkiego. Wytrzymałość tych zapraw maleje odpowiednio tylko o $4 \%$ i $6 \%$. Jest to spowodowane mniejszym udziałem cementu portlandzkiego CEM I 42,5R w tych spoiwach (tzw. „efekt rozcieńczenia”). Natomiast w przypadku zaprawy zawierającej $5 \%$ pyłu obserwuje się wzrost wytrzymałości, a różnica wynosi około $6 \% \mathrm{w}$ stosunku do cementu portlandzkiego. Jest to prawdopodobnie spowodowane aktywacją procesu hydratacji spoiwa zawierającego pył z bypassa na skutek 
with the addition of dust. The hydration of $\mathrm{CaO}$ gives significant changes in the volume of hardened cement mortar (lack of volume stability). In effect, the causing stretching stress are formed in hardened cement paste, which negatively affect the strength of material.

Taking into account the requirements of standard PN-EN 197-1, the addition of $1 \%$ bypass dust does not cause the decrease in cement strength class (cement strength class of $42.5 \mathrm{R}$ ). The incorporation of $5 \%$ bypass dust gives cement strength class of $32.5 \mathrm{R}$.

The autoclave curing improves the compressive strength gain of cement mortars. After 2 days, the strength of autoclaved cement containing $5 \%$ of bypass dust is increased to $55.60 \mathrm{MPa}$, whereas that of autoclaved Portland cement is only 50.05 MPa. After 28 days, the strength of these mortars is respectively 64.85 $\mathrm{MPa}$ and $69.85 \mathrm{MPa}$. The increase in strength of autoclave cement mortars can be explained by the fact that the use of hydrothermal treatment allows the formation of C-S-H of higher crystallization degree and well-formed tobermorite fibres, which in effect cement mortar can represents higher strength. wprowadzenia wraz z pyłem większej ilości alkaliów (największy udział pyłu w tym spoiwie) w porównaniu do innych zapraw, zwłaszcza w stosunku do zaprawy kontrolnej.

Po 28 dniach wszystkie zaprawy cementowe z dodatkiem pyłu z bypassa reprezentują niższą wytrzymałość na ściskanie niż cement portlandzki. Może to być konsekwencją wzrostu udziału wolnego $\mathrm{CaO}$ w cementach przy dodatku pyłu. Hydratacja $\mathrm{CaO}$ powoduje zmiany objętości stwardniałej zaprawy cementowej (brak stałości objętości). W efekcie w stwardniałym zaczynie cementowym powstają naprężenia rozciągające, które negatywnie wpływają na wytrzymałość materiału.

Zgodnie z wymaganiami normy PN-EN 197-1, dodatek $1 \%$ pyłu $\mathrm{z}$ bypassa nie powoduje zmiany klasy wytrzymałości cementu (cement klasy wytrzymałości 42,5R). Natomiast przy dodatku 5\% pyłu można uzyskać cement klasy wytrzymałościowej 32,5R.

Próbki zapraw poddane procesowi autoklawizacji wykazują większy przyrost wytrzymałości na ściskanie. Po dwóch dniach autoklawizacji, wytrzymałość zaprawy zawierającej $5 \%$ pyłu z bypassa wzrasta do $55,60 \mathrm{MPa}$, podczas gdy wytrzymałość zaprawy z cementu portlandzkiego wynosi tylko 50,05 MPa. Po 28 dniach autoklawizacji, wytrzymałość tych zapraw wynosi odpowiednio 64,85 MPa i 69,85 MPa. Wzrost wytrzymałości na ściskanie zaprawy po autoklawizacji można tłumaczyć tym, że zastosowanie obróbki hydrotermalnej pozwala na powstanie fazy C-S-H o wyższym stopniu wykrystalizowania, a także tobermorytu w postaci dobrze wykształconych igieł, dzięki czemu zaprawa cementowa może uzyskiwać wyższą wytrzymałość [27].

\section{REFERENCES}

[1] Al-Jabri K., Taha R., Al-Ghassani M.: Use of copper slag and cement by-pass dust as cementitious materials. Cement Concrete Aggregates, 24 (2002) 7-12.

[2] Al-Jabri K.S., R.A. Taha, Al-Hashmi A., Al-Harthy A.S.: Effect of copper slag and cement by-pass dust addition on mechanical properties of concrete. Construction and Building Materials, 20 (2006) 322-331.

[3] El-Didamony H., Helmy I.M., Amer A.: Utilization of cement dust in blended cement. Pakistan Journal of Scientific and Industrial Research, 35 (1993) 304-308.

[4] Stryczek S., Gonet A.A., Wiśniowski R., Biskup T.: Wpływ pyłów cementowych z Cementowni Chełm na właściwości technologiczne zaczynów uszczelniających. Wiertnictwo Nafta Gaz, 26 (2009) 677-687.

[5] Pavía S., Regan D.: Influence of cement kiln dust on the physical properties of calcium lime mortars. Materials and Structures, 43 (2010) 381-391.

[6] Adaska W.S., Taubert D.H.: Beneficial uses of Cement Kiln Dust, in: EEE/PCA 50th Cement Industry Technology Conference, Miami, 2008.

[7] Todres H.A., Mishulovich A., Ahmed J.: Cement kiln dust management: permeability. Research and Development Bulletin RD 103T, Portland Cement Association, Skokie, 1992.

[8] Maslehuddin M., Al-Amoudi O.S.B., Shameem M., Rehman, M.K. Ibrahim M.: Usage of cement kiln dust in cement products - research review and preliminary investigations. Construction and Building Materials, 22 (2008) 2369-2375. 
[9] Peethamparan S., Olek J., Lovell J.: Influence of chemical and physical characteristics of cement kiln dusts (CKDs) on their hydration behavior and potential suitability for soil stabilization. Cement and Concrete Research, 38 (2008) 803-815.

[10] Siddique R.: Utilization of cement kiln dust (CKD) in cement mortar and concrete - an overview. Resources, Conservation and Recycling, 48 (2006) 315-338.

[11] Khudhair M., Elharfi A.: Formulation of the cement kiln dust (CKD) in concrete: Studies of the physical-chemical and mechanical properties. International Journal of ChemTech Research, 9 (2016) 695-704.

[12] Heikal M., Aiad I., I.M. Helmy: Portland cement clinker, granulated slag and by-pass cement dust composites. Cement and Concrete Research, 32 (2002) 1805-1812.

[13] Mostafa H.M., Rashed E.M., Mostafa A.H.: Utilizations of by-pass kiln dust for treatment of tanneries effluent wastewater, in: 9th International Water Technology Conference, WTC9 2005, Sharm El-Sheikh, 2005, 133-141.

[14] Keerthi Y., Divya Kanthi P., Tejaswi N., Shyam Chamberlin K., Satyanarayana B.: Stabilization of clayey soil using cement kiln waste. International Journal of Advanced Structures and Geotechnical Engineering, 2 (2013) 2319-5347.

[15] Miller G.A., Azad S.: Influence of soil type on stabilization with cement kiln dust. Construction and Building Materials, 14 (2000) 89-97.

[16] Albusoda B.S., Salem L.A.K., Salem K.: Stabilization of dune sand by using cement kiln dust (CKD). Journal of Earth Sciences and Geotechnical Engineering, 2 (2012) 131-143.

[17] Farhan S., Sharif A.: Influence of cement kiln dust as partial replacement on some properties of ordinary and white Portland cement. Tikrit Journal of Engineering Sciences, 18 (2011) 23-32.

[18] Abd El-Aleem S., Abd-El M.A., Heikal M., Abd-El-Aziz M.A.: Effect of cement kiln dust substitution on chemical and physical properties and compressive strength of Portland and slag cements. Arabian Journal for Science and Engineering, 30 (2005) 263-273.

[19] Duszak B., Adamski G., Foszcz T., Laska-Józefczak P.: Badania zawartości pierwiastków i zwiazków szkodliwych w procesie produkcji cementu w pyłach z pieców obrotowych. Prace Instytutu Ceramiki i Materiałów Budowlanych, 22 (2015) 263-273.

[20] Maslehuddin M., Al-Amoudi O.S.B., Rahman M.K., Ali M.R., Barry M.S.: Properties of cement kiln dust concrete. Construction and Building Materials, 23 (2009) 2357-2361.

[21] El-Didamony E., Amer A.A., Ebied E., Heikal M.: Role of cement dust in some blended cements. Cemento, 90 (1993) 221-230.

[22] Bhatty M.S.: Kiln dust cement blends evaluated. Rock Products, 88 (1985) 47-52.

[23] Bhatty M.S.: Use of cement kiln dust in blended cements. World Cement, 15 (1984) 126-134.

[24] Bogue R.H.: Calculation of the compounds in Portland cement. Industrial and Engineering Chemistry Analytical Edition, 1 (1929) 192-197.

[25] Collin R.J., Emery J.J.: Kiln dust-fly ash systems for highway bases and subbases, FHWA/RD-82/167, Washington, 1983.

[26] Kunal, Siddique R., Rajor A.: Use of cement kiln dust in cement concrete and its leachate characteristics. Resources, Conservation and Recycling, 61 (2012) 59-68.

[27] Walczak P.: Wpływ autoklawizacji na proces hydratacji na przyktadzie autoklawizowanego betonu komórkowego. Prace Instytutu Ceramiki i Materiałów Budowlanych, 30 (2017) 127-139.

[28] Ravindrarajah R.S.: Usage of cement kiln dust in concrete. International Journal of Cement Composites and Lightweight Concrete, 4 (1982) 95-102.

[29] MarkuJ. , Dumi I., Lico E., Dilo T., Cakaj O.: The characterization and theutilization of cement kiln dust (CKD) as partial replacement of Portland cement in mortar and concrete production. Zastita Materijala, 53 (2012) 334-344.

[30] Khalil K.A., Abd-El-Hameed N.M.: Physicochemical characteristics of slag rich cement pastes incorporated bypass cement dust. Egyptian Journal of Chemistry, 59 (2016) 491-507.

[31] Shoaib M.M., Balaha M.M., Abdel-Rahman A.G.: Influence of cement kiln dust substitution on the mechanical properties of concrete. Cement and Concrete Research, 30 (2000) 371-377.

[32] Coleman N.J., Trice C.J., Nicholson J.W.: 11 A tobermorite from cement bypass dust and waste container glass: $a$ feasibility study. International Journal of Mineral Processing, 93 (2009) 73-78.

[33] Huang Z.M., Yuan Y.F., Chen Z.J., Wen Z.Y.: Microstructure of autoclaved aerated concrete hydration products in different water-to-binder ratio and different autoclaved system. Advaced Materials Research, 602-604 (2012) 1004-1009.

[34] Cai L., Ma B., Li X., Lv Y., Liu Z., Jian S.: Mechanical and hydration characteristics of autoclaved aerated concrete (AAC) containing iron-tailings: effect of content and fineness. Construction and Building Materials, 128 (2016) 361-372. 
[35] Narayanan N., Ramamurthy K.: Structure and properties of aerated concrete: a review. Cement and Concrete Composites, 22 (2000) 321-329.

[36] Alexanderson J.: Relations between structure and mechanical properties of autoclaved aerated concrete. Cement and Concrete Research, 9 (1979) 507-514.

\section{Acknowledgments:}

The work was financed by the AGH University of Science and Technology in Krakow as part of the Faculty of Materials and Materials Science and Ceramics, $A G H$ University of Science and Technology no: 5.5.160.763

\section{Podziękowania:}

Praca była finansowana przez Akademię Górniczo-Hutnicza w Krakowie w ramach Wydziatu i Materialoznawstwa i Ceramiki, AGH Uniwersytet Nauki i Techniki $n r: 5.5 .160 .763$ 